\title{
SUSPENSION AND EXPULSION OF MEMBERS OF THE COUNCIL OF EUROPE: DIFFICULT DECISIONS IN TROUBLED TIMES
}

\author{
Kanstantsin Dzehtsiarou and Donal K Coffey*
}

\begin{abstract}
The effectiveness and legitimacy of the Council of Europe can be undermined by the actions of Member States which fail to comply with their international law obligations of genuine cooperation with the organization. This article first briefly examines the practice of international organizations in applying sanctions such as expulsion and suspension to their members. It then explains why it is necessary to discuss potential sanctions that the Council can apply in the context of current controversies involving the Council and Member States. It will be argued that the scale and intensity of challenges distinguish the current state of affairs from other 'problematic' periods in the Council's history. It proceeds to outline the considerations that should be taken into account in deciding whether a Member State should be suspended or expelled. These considerations include the implications of sanctions on the legitimacy of the Council of Europe, the level of human rights protection and the financial stability of the organization.
\end{abstract}

Keywords: public international law, human rights law, legitimacy, Council of Europe, European Court of Human Rights, expulsion, suspension, sanctions, Committee of Ministers of the Council of Europe, Parliamentary Assembly of the Council of Europe.

\section{INTRODUCTION}

The European legal systems are in crisis. Brexit means that the legal order of the European Union, founded on a policy of integration, faces a fundamental challenge. The other great European legal order, that of the Council of Europe (CoE), faces a more insidious crisis: the liberal system on which it is based is being undermined through more subtle means by some States. The nature of this crisis prompts consideration of the steps that might be taken to deal with it. This article proposes a new approach to the question of when and how the Statute of the CoE should be invoked in relation to the

* Senior lecturer, University of Liverpool, k.dzehtsiarou@liverpool.ac.uk; Senior research fellow, Max Planck Institute for European Legal History, Frankfurt-am-Main, coffey@rg.mpg.de. We are grateful to Bill Bowring, Andrew Drzemczewski, Andrew Forde, Vassilis Tzevelekos, Ben Kamis and the anonymous reviewers for their insightful comments on the earlier drafts of this article. Usual disclaimers apply. 
suspension and expulsion of Member States for failing to comply with their obligations under the Statute. Such an important decision as suspension or expulsion inevitably attracts multiple arguments for and against it. This article suggests a framework that would assist decision-makers in systematizing and weighing the competing arguments.

The analysis is based on the experience of other international organizations in applying sanctions of suspension and expulsion. There is no consensus on the question of the use of such sanctions. Some commentators argue that expulsion is not a good idea because it cuts all the ties between the State in question and the organization, which prevents the organization influencing the State. ${ }^{1}$ However, this argument does not apply equally to every international organization. The $\mathrm{CoE}$ is a regional organization that is designed to promote human rights, democracy and the rule of law. If one of its members seriously violates these principles it undermines the credibility of the whole organization, making it unable to fulfil its statutory functions. Therefore, this article, whilst based on the experience of international organizations generally, pays particular attention to the role and the function of the CoE. The arguments advanced are those most appropriately directed towards regional human rights organizations.

In this article we examine the behaviour of States, particularly behaviour that shows a persistent and clear disregard of the values and aims of the CoE. We consider the examples of Russia, Turkey and Azerbaijan but this list is not exhaustive. The practice of Russia that we are concerned with is relates to its occupation of a part of the territory of another Member State of the CoE, its support for separatist movements in the region, its refusal to collaborate with the $\mathrm{CoE}$ and its failure to comply with the judgments of the European Court of Human Rights (ECtHR). The attempts to undermine the legitimacy of the ECtHR by Turkey's failure to execute its rulings and Turkish actions in relation to financial contributions to the CoE budget are also a cause for concern. We also consider the case of Azerbaijan, due to the Azerbaijani authorities' lack of respect for human rights, the existence of political prisoners in the country, accusations of corruption and failure to enforce the judgments of the ECtHR.

The examples considered in this article necessarily implicate involve questions of the field of politics and international relations. There exists rich literature in these fields dealing with international organizations. We are primarily concerned with a legal analysis of the provisions relating to suspension and expulsion, but it is clear that this cannot be considered in monastic seclusion from politics and international relations. Accordingly we

1 See eg N White, The Law of International Organisations (Manchester University Press 1996), 64; F Morgenstern, Legal Problems of International Organizations (Cambridge University Press 1986), 53; C Amerasinghe, Principles of the Institutional Law of International Organizations (2nd edn, Cambridge University Press 2005), 123; CW Jenks, 'Expulsion from the League of Nations' (1935) 16 British Yearbook of International Law 155. 
try to incorporate insights from these fields, where appropriate, in our analysis. The primary focus of this article is, however, legal, and it outlines justifications and motivations for possible decisions that might be taken by the CoE.

This is useful because in the interests of legitimacy and transparency the Committee of Ministers of the CoE and the Parliamentary Assembly of the $\mathrm{CoE}(\mathrm{PACE})^{2}$ have to explain and justify decisions to suspend or expel a Member State. Therefore, this article offers a comprehensive overview of the procedure and factors that can influence suspension and expulsions of members. It also argues that decision-makers should be more eager to apply sanctions to those States which persistently violate foundational values of the CoE.

This argument will be unpacked in stages and the emphasis will be placed on the legitimacy of a decision of the CoE to suspend or expel members. Section II of this article briefly explains the practice of international organizations concerning expulsion. As we shall see, commentators often point out that expulsion is a fruitless sanction when it comes to global organizations which are dedicated to peace and security. We argue here that the CoE can be distinguished from the main examples considered in the literature. Section III shows that although the $\mathrm{CoE}$ is entitled to expel its members, the regulations setting out the relevant procedures are laconic and require interpretation. We offer our view on how this process can be conducted. Section IV argues that decisions to expel have at least three aspects: a legal right to expel, the factual matrix giving rise to and surrounding the crisis and an interpretation of the pros and cons of expulsion. This framework is then applied to the situation of the CoE. Section V draws attention to the signs of a crisis of the CoE: a lack of genuine commitment to collaborate is intertwined with financial threats to the organization. The $\mathrm{CoE}$ needs to respond firmly to these challenges in order to preserve the legitimacy and reputation of the organization and to reinforce its role in protecting human rights, the rule of law and democracy. Section VI then examines the factors that should be considered when applying suspension or expulsion procedures. It analyses how the legitimacy of an international organization can be reduced or enhanced through the use or failure to use such means. It suggests two issues need to be reflected on when considering whether suspension should be applied. First, it argues that if the continued membership of a particular State in the $\mathrm{CoE}$ is more detrimental for the legitimacy, effectiveness and reputation of the organization than its expulsion then this should result in a preference for expelling or suspending the State. Second, it concludes that some worsening of the levels of human rights protection of individuals cannot endlessly justify continued membership if the CoE is incapable of strategically improving the situation regarding human rights protection in the

\footnotetext{
2 These are two key decision-making bodies when it comes to the suspension and expulsion of Member States.
} 
State in question. These two sets of considerations should, we argue, inform the interpretation of Articles 7 and 8 of the Statute of the CoE which provides the legal basis for the suspension and expulsion of members of the CoE.

\section{TO EXPEL OR NOT TO EXPEL: AN EXISTENTIAL DILEMMA OF INTERNATIONAL}

\section{ORGANIZATIONS}

The scholarly literature demonstrates no consensus on whether or not the expulsion of States is justified. Some commentators oppose the idea of expulsion because after using this 'clumsy weapon' 3 the organization is no longer able to put any pressure on the 'recalcitrant member' ${ }^{4}$ This argument is has particular force in relation to global organizations whose key objectives include peace, integration and cooperation. ${ }^{5}$ Indeed, there are very few examples of expulsion from such global organizations. ${ }^{6}$ Regional human rights organizations are, however, subject to different considerations. For 'closed' regional organizations, such as the $\mathrm{CoE}$, it is important that members share common values and actively engage in achieving its aims. ${ }^{7}$ An attempt by a member State to undermine the values of an organization which has a relatively limited number of members has arguably a greater impact than would such action in a global organization. Even in cases such as this, expulsion should only be used when the organization is unable to fulfil its statutory functions through another means.

The aims of the CoE are stated in Article 1 of its Statute (1949):

A. The aim of the $\mathrm{CoE}$ is to achieve a greater unity between its members for the purpose of safeguarding and realising the ideals and principles which are their common heritage and facilitating their economic and social progress.

B. This aim shall be pursued through the organs of the Council by discussion of questions of common concern and by agreements and common action in economic, social, cultural, scientific, legal and administrative matters and in the maintenance and further realisation of human rights and fundamental freedoms.

These aims can only be achieved if the CoE is formed of like-minded States that share a commitment to 'individual freedom, political liberty and the rule of law, principles which form the basis of all genuine democracy', as the Preamble to the Statute puts it. The use of the $\mathrm{CoE}$ as a baseline on which to build international cooperation can be seen in the hundreds of treaties which it has

3 CW Jenks, 'Due Process of Law in International Organizations' (1965) 19 IntlOrg 163, 166.

4 Amerasinghe (n 1) 123-4; A Duxbury, The Participation of States in International Organisations: The Role of Human Rights and Democracy (CUP 2011). See also White (n 1) 64; LB Sohn, 'Expulsion or Forced Withdrawal from an International Organization' (1964) 77 HarvLRev 1381.

5 Morgenstern (n 1) 53; Amerasinghe (n 1) 123.

6 The Union of Soviet Socialist Republics was expelled from the League of Nations.

7 Jenks (n 3) 160. 
concluded. ${ }^{8}$ Much has been done to ensure a high level of human rights protection in Europe: the Convention for the Protection of Human Rights and Fundamental Freedoms and the European Court of Human Rights are, by common consensus, the most effective system of regional human rights protection in the world. ${ }^{9}$

The focus on human rights, the rule of law, democracy and peaceful cooperation makes the $\mathrm{CoE}$ especially prone to considering expulsion as a sanction of last resort. The aim of sanctioning is to ensure that the Member States comply with the normative obligations of the organization. The secondary aim is to maintain the legitimacy of the organization more generally. In other words, a State may be expelled if there is no other way in which to induce or compel it to comply with its obligations. At the same time, expulsion may increase the legitimacy of the international organization by showing that it takes compliance seriously.

There are some discernible patterns in the reasons given for and the means by which suspension and expulsion of members are carried out by international organizations, three of which are noteworthy for the purposes of this article. First, the founding documents of an international organization should explicitly provide for the possibility of expulsion. If the statute of an international organization does not provide for such a power, and there are examples of this, then an expulsion may be considered to be illegitimate. ${ }^{10}$

Second, there there needs to be more than the normal levels of dispute within an organization: there must be a crisis. By this, we mean that the Member States being considered for expulsion should be showing serious disregard for the statutory aims of the organization. The crisis should reach a certain magnitude before the question of expulsion arises, eg an act of aggression in an organization dedicated to peace.

Finally, even if the statute of an international organization provides for the possibility of expulsion, it should only use this sanction as a matter of last resort and after carefully considering all relevant factors. This article will briefly look at the practice of international organizations to establish some common patterns in relation to these three aspects of expulsion.

\footnotetext{
8 On 11 February 2019, this stood at over 220 treaties; see complete list of the Council of Europe's treaties at $<$ https://www.coe.int/en/web/conventions/full-list $>$.

9 See 'Defending the Acquis of the Council of Europe: Preserving 65 Years of Successful Intergovernmental Co-operation' (Council of Europe, 27 September 2017) <http:/semantic-pace. net/tools/pdf.aspx?doc=aHR0cDovL2Fzc2VtYmx5LmNvZS5pbnQvbncveG1sL1hSZWYvWD JILURXLWV4dHIuYXNwP2ZpbGVpZD0yNDAzMyZsYW5nPUVO\&xsl=aHR0cDovL3Nlb WFudGljcGFjZS5uZXQvWHNsdC9QZGYvWFJ1Z i1XRC1BVC1YTUwyUERGLnhzbA==\& xsltparams $=$ ZmlsZWlkPTI0MDMz $>$.

${ }^{10}$ For example the Charter of the Organization of American States as adopted in 1948 did not have any provisions of membership sanctions.
} 


\section{THREE ASPECTS OF EXPULSION}

\section{A. Legal Power to Expel}

While some international organizations lack a clear power to expel, this is not the case in relation to the $\mathrm{CoE}$ where the power is enshrined in the Statute. ${ }^{11}$ Two points should be noted. First, an explicit power to expel is more weighty than a non-textual expulsion power. Although a non-textual power has been used in some cases, a textually-grounded power has a stronger base. Second, it could be argued that a power to expel implies that some leeway might be given to newly acceding States whose compliance with core obligations needs improving. We will consider these two observations in turn.

The Charter of the Organization of American States as adopted in 1948 did not explicitly provide for expulsion. After the Cuban revolution in 1958, this lacuna was regarded as problematic by the other members. ${ }^{12}$ Notwithstanding the lack of an express provision, other members declared that the government of Cuba had 'placed itself outside the inter-American system'. ${ }^{13}$ This creative reading of the founding document was not accepted by all Member States. ${ }^{14}$ Fenwick, on the other hand, has argued that if a Member State violates a foundational document of an international organization this organization has an implied right to expel. ${ }^{15}$ It is not necessary to consider which side had the better of the argument, it is sufficient to note that the legitimacy of expulsion is far greater where there is an explicit power to expel.

The power to expel can sometimes be linked to arguments in favour of taking an accommodating approach to states when they first accede to an organization. The Russian accession to the CoE illustrates this point. Many argued that Russia was not ready to join the CoE in the late 1990s. ${ }^{16}$ However, one of the arguments in favour of its accession given by David Atkinson, a British delegate to the Assembly, was that if Russia failed to fulfil its obligations, it could always be suspended. ${ }^{17}$ Despite a clearly established expulsion power, however, the practical application of Atkinson's argument is rather more difficult once a State has become a member of an international organization. ${ }^{18}$

11 Art 8 of the Statute of the CoE, 1949.

12 See Duxbury (n 4) 174.

13 'Resolution VI - Exclusion of the Present Government of Cuba from Participation in the Inter-American System', Final Act, Eighth Meeting of Consultation of Ministers of Foreign Affairs, Punta del Este, Uruguay, Doc No OEA/Ser.C/II.8 (22-31 January 1962).

14 See Sohn (n 4) 1418.

15 CG Fenwick, 'The Issues at Punte Del Este: Non-Intervention v. Collective Security' (1962) 56 AJIL 469, 474.

16 B Bowring, 'Russia's Accession to the CoE and Human Rights: Compliance or CrossPurposes?' (1997) 6 EHRLR 628, 631-3.

17 'CoE Votes Russia In' Financial Times (London, 26 January 1996) 2.

18 K Magliveras, Exclusion from Participation in International Organisations (Kluwer 1999) 87. 


\section{B. Crisis}

A sustained failure by a Member State to comply with its obligations could be considered as a sign of crisis within an international organization. Notwithstanding this point, there is no consistency concerning how a crisis is to be understood and what precisely would constitute a reason for initiating expulsion procedures. Moreover, it is not entirely clear what sort of evidence an international organization should produce in order to substantiate its decision to suspend or expel. Judging from the practice of various international organizations three main reasons are usually viewed as being serious enough to initiate suspension and expulsion: first, a change of political regime from democratic to anti-democratic; second, an act of armed aggression; and finally, human rights violations and a failure to cooperate with the international organization. In practice, there is normally a combination of these reasons but for analytical purposes we will discuss them in turn.

The abrupt change of political regime was a reason why Cuba was effectively expelled from the Organization of American States. In 2010, Niger was suspended from the African Union because of a military coup. ${ }^{19}$ The history of the CoE also provides an example of suspension as a result of a sudden change of government.

A military coup occurred in Greece in 1967, as a result of which an interstate application against the Greek government was brought by Denmark, Norway, Sweden, and the Netherlands pursuant to what is now Article 33 of the ECHR. The now defunct European Commission on Human Rights found that the derogations from the ECHR made by Greece were not justified under Article 15 and that the Greek government was therefore in systemic breach of the provisions of the Convention. Becket records two views within the organs of the Council: one was to simply expel Greece for being in violation of the Convention and the rules of the Council, the other was that it was necessary to keep Greece within the system since the Council would have no influence on Greece if it were expelled. ${ }^{20}$ Becket also notes that behind the first view was the belief that only the restoration of democratic governance would solve the crisis and expulsion could help bring this about. The same sort of dilemma exists in relation to the questions posed by the actions of States towards the $\mathrm{CoE}$ today. The narrative is often framed in terms of whether to expel a member from an international organization as a result of its failure to comply with the normative structure, or to keep it within the system in order to retain some influence over it notwithstanding its breaches. In the Greek case, the situation was taken out of the hands of the CoE by the Greek government's withdrawal from the CoE.

\footnotetext{
19 For more details see Duxbury (n 4) 191.

20 J Becket, 'The Greek Case before the European Human Rights Commission' (1970) 1(1) Human Rights 91, 106.
} 
A second sign of crisis is an act of aggression. Yugoslavia was excluded from the Conference for Security and Cooperation in Europe (CSCE) because of its aggression against neighbouring countries in 1992. Yugoslavia was excluded for 'clear, gross and uncorrected violations of relevant CSCE principles';21 the act of aggression was given as a reason for this unwillingness to allow Yugoslavia to continue to participate in the organization. ${ }^{22}$ This reason is relevant to the current context of the CoE. Russian occupation of Crimea was the key reason for the standoff between the Russian government and the PACE. This issue will be dealt in more detail below, and it suffices to say here that military aggression can clearly give rise to the question of expulsion.

Finally, the lack of cooperation with the organization and gross violations of human rights can also be considered as reasons for expulsion. This lacks the immediacy of the other reasons but it is a reflection of a slow deterioration in the human rights situation in the country to the point where any effective collaboration with an organization based on human rights values becomes impossible. In order to establish this, there must be a pattern of ignoring key human rights obligations. A Member State needs to have both grossly violated human rights and refuse to collaborate with the international organization in attempting to rectify this. It seems that this reason, more than others, requires substantiation and evidence that human rights violations of a particular magnitude have in fact occurred.

Critics of this reason to expel argue that in practice organizations have tended to restrict the use of suspension to a limited range of behaviours, suggesting a selective approach to rights enforcement'. ${ }^{23}$ To respond to this criticism, a decision to expel on this basis should be well substantiated and based, for example, on an interstate judgment of the ECtHR or a decision made under the infringement procedure provided for in Article 46(4) ECHR. Expulsion for this reason can serve to strengthen the underlying values that the organization is committed to. Expulsions on this basis can take place in conjunction with the other reasons outlined above. Human rights violations have served as the basis for suspension and expulsion proceedings in some international organizations.

The Commonwealth of Nations offers an example of how expulsion can work to strengthen the normative core of an international organization. ${ }^{24}$ In 2009 , Fiji was suspended for restrictions on freedom of expression and assembly, arbitrary arrest and breaches of principle of judicial independence. ${ }^{25}$ In 2002, Zimbabwe

\footnotetext{
21 Prague Document on Further Development of CSCE Institutions and Structures', Second Meeting of the Council, Doc No 2PRAG92.e (1992) para 16.

22 'Sixteenth CSO Meeting, Decisions of the Committee of Senior Officials, Prague, 16-18 September 1992' in A Bloed (ed), The Conference on Security and Co-operation in Europe: Analysis and Basic Documents, 1972-1993 (Brill 1993) 962.

${ }^{3}$ Duxbury (n 4) 214.

${ }^{24}$ The Commonwealth did not originally provide a means to leave, this was solved through political fiat; see DK Coffey, “The Right to Shoot Himself”: Secession in the British Commonwealth of Nations' (2018) 39 Journal of Legal History 117.

25 Duxbury (n 4) 208.
} 
was suspended from the ministerial councils as a result of politically motivated violence which had occurred in the presidential election in March 2002. ${ }^{26}$ The initial 12-month suspension was to be followed by an indefinite suspension, at which point Zimbabwe withdrew from the Commonwealth. ${ }^{27}$ This was driven by the need to uphold human rights norms and also by the failure of Zimbabwe to engage with the process initiated in 2002 to promote reconciliation. $^{28}$

\section{Interpretation}

Even when an organization has a legal right to expel and there are reasons to do so, such an organization has to carefully weigh all relevant considerations and consequences of this decision. A decision to expel or not might have important consequences for the future of the organization. In the past, some organizations have made a strategic decision to avoid expulsions. For instance, Sohn observed that, despite having the ability to expel, the League of Nations did not even formally attempt to expel Japan for its aggression against China or Italy for its aggression against Ethiopia: 'Both Japan and Italy, and Germany as well, withdrew from the League, and the efforts of most nations were devoted to urging them to retain their membership.' ${ }^{29}$ This strategy proved fatal for this organization.

Legal provisions that empower an international organization to suspend and expel its members leave broad areas for discretion and political decisionmaking. The subsequent sections consider whether the $\mathrm{CoE}$ can legally suspend and terminate the membership of its members, whether there are signs of crisis in the CoE and, finally, it offers a framework of analysis that would assist the $\mathrm{CoE}$ to balance the pros and cons of expulsion of its members.

IV. LEGAL REGULATION OF SUSPENSION, TERMINATION OF MEMBERSHIP AND REQUEST TO WITHDRAW

This section explores the legal background of expulsion. Unlike statutes of some other international organizations, ${ }^{30}$ the Statute of the CoE clearly gives

\footnotetext{
26 See 'Commonwealth Marlborough House Statement on Zimbabwe' < http://www.dirco.gov. $\mathrm{za} /$ docs/2002/zimb0319a.htm>. On the background to the 2002 elections, see I Taylor and P Williams, 'The Limits of Engagement: British Foreign Policy and the Crisis in Zimbabwe' (2002) 78(3) IntlAff 547.

27 The Zimbabwean Government argued that the initial 12-month suspension automatically lapsed unless it was renewed, although the Commonwealth Head of Government Meeting did not agree with this view.

${ }_{28}$ Other countries who chose to engage at a similar time, eg Pakistan, were not subject to the same procedure.

29 Sohn (n 4) 1388.

30 See eg the Charter of the Organization of American States.
} 
it a power to suspend and expel its members. There are challenges as to the practical application of this right ${ }^{31}$ but the right is there.

The suspension and termination of membership are regulated by Article 8 of the Statute of the CoE. It provides that any member of the $\mathrm{CoE}$ which has seriously violated Article 3 may be suspended from its rights of representation and requested by the Committee of Ministers to withdraw under Article 7. Article 3 establishes that all members of the CoE should accept the principles of the rule of law and human rights and that they should collaborate sincerely and effectively in the realization of the aims of the Council. Pursuant to Article 8 of the Statute, if a Member State that was requested to withdraw does not comply, the Committee may decide that it has ceased to be a member of the Council. Article 8 makes the Committee of Ministers an ultimate decision-maker in the process of suspension and termination of membership, subject to consultation with the PACE. ${ }^{32}$ The Rules of Procedure of the Committee of Ministers are quite concise and lack guidelines as to how the decisions of suspension and expulsion should be made in practice. Article 26 only provides that

All consideration of the suspension of a member must begin by a proposal for suspension put forward by at least one representative. The proposal must have been included in the agenda of the session at which it is discussed. The member concerned shall receive through the Secretary General a notification of the decision reached in its case. This notification shall set out the legal and financial consequences of the decision. ${ }^{33}$

According to Article 27 of the Rules of Procedure the same mechanism should be followed when the Committee is deciding whether the suspended member should cease to be a member or cease to be suspended. There are a few possible modalities of how this procedure can operate in practice. The process of suspension and expulsion can be logically divided into two stages: 'trigger' and 'response'.

By 'trigger' we mean events, statements or processes that can act as reasons to commence the procedure. The statutory documents of the $\mathrm{CoE}$ are quite vague as to what can trigger the Article 8 procedure. A failure to comply with Article 3 of the Statute is sufficient, but only if it has been 'seriously violated', although this term is not defined. Thus, any Member State can propose that the Committee of Ministers consider suspension of a Member

31 By way of example, Magliveras examined the procedural difficulties of expelling Greece from the $\mathrm{CoE}$ in the $1960 \mathrm{~s}$. He points out '[a] controversy erupted as to the whether the resolution on suspension required unanimity or qualified majority. Whereas voting is regulated in Art 20 of the Statute, suspension is not mentioned as an "important matter" requiring unanimity. As Art 20 does not stipulate that interested parties are excluded from voting, this does not prevent the recalcitrant State from casting a negative vote, effectively vetoing the adoption of the resolution on suspension. The adopted solution was to apply the voting conditions regulating admission of new Members by analogy; thus, a two-thirds majority was sufficient.' $\quad{ }_{32}$ Res (51)30; Magliveras (n 18) 81.

33 26 of the Rules of Procedure of the Committee of Ministers. 
State for violation of Article 3. This is particularly problematic because of the abstract nature of the values protected under Article 3-human rights, democracy, and the rule of law-makes a determination of 'serious violation' difficult to assess. A more precise trigger would certainly be fairer and more transparent. Moreover, other international organizations have been criticized for a lack of transparency in relation to the reasons for which suspension or expulsion procedures were triggered. ${ }^{34}$

In the 1960s, a decision of the European Commission on Human Rights finding numerous violations of the European Convention on Human Rights in Greece acted as such a trigger. ${ }^{35}$ Indeed, a 'trigger' which seems to meet the Article 8 requirements could be an interstate judgment of the ECtHR identifying mass violations of human rights in a situation which is still ongoing. A report by the PACE or investigation by the Human Rights Commissioner describing mass violations of human rights can perhaps also trigger the Article 8 procedure. A decision of the ECtHR under Article 46(4) ECHR confirming failure to implement a judgment of the Court can potentially also act as such a trigger. Article 46(4) introduced an infringement procedure for refusal to abide by an ECtHR judgment. According to this procedure the Committee of Ministers can 'send' a case back to the Grand Chamber of the ECtHR to establish that the State in question failed to implement the judgment. ${ }^{36}$ It is unlikely that after the Court's extraordinary judgment pursuant to Article 46(4), the Committee of Ministers would continue ordinary supervision of the execution of the original judgment. The Court might indicate a time limit to enforce its Article 46(4) judgment and after that the Committee of Ministers should raise the question of suspension.

By 'response' we mean the procedures and actions within the CoE that follow the trigger. Luckily, the CoE has not had many opportunities to 'polish' its procedures of expulsion. Therefore, the Committee of Ministers will be sailing in uncharted waters if the suspension procedure is triggered. It is argued here that it is logical that the suspension and expulsion procedures would mirror the admission procedures. The $\mathrm{CoE}$ has greater experience in admitting members and this experience can be used in the unfortunate event of expulsion. Guy de Vel explains the process of granting membership in the CoE:

The Committee of Ministers requests the Assembly to express its opinion in the form of a resolution. [They] often contain messages to the Assembly relating to the problems or questions of particular concern to the Committee of Ministers. Once the Assembly has given its opinion, the Committee of Ministers adopts, if

34 See Duxbury (n 3) 714.

35 Denmark, Norway, Sweden and the Netherlands v Greece, No 3321/67, 3322/67, 3323/67, 3344/67.

36 The effectiveness of this procedure is discussed in F de Londras and K Dzehtsiarou, 'Mission Impossible? Addressing Non-execution through Infringement Proceedings in the European Court of Human Rights' (2017) 66(2) ICLQ 467. 
appropriate, a resolution inviting the applicant State to become a member and instructing the Secretary General to address the invitation to its government The powers vested in the Committee of Ministers regarding the admission of new members may be exercised - as indeed they are in most cases at present by the Ministers' Deputies. A decision to invite a State to join the Organisation, however, requires, at ministerial level, a majority of two-thirds of the representatives entitled to sit on the Committee, while at Deputies' level a unanimous vote is required. ${ }^{37}$

The resolution of the Committee of Ministers should invite the PACE to express its opinion whether this suspension is indeed necessary. In the interest of transparency and fairness the Committee of Ministers must disclose the trigger for its decision to initiate the Article 8 procedure. The PACE can then comment on each individual reason and generally on the necessity of suspension of membership. ${ }^{38}$

After obtaining the opinion of the PACE, the Committee of Ministers might decide on suspension of membership. It seems that the Committee of Ministers can give the Member State under question some time to show its willingness to collaborate and set clear indicators that need to be fulfilled in a certain period of time. If the State fails to comply then the Committee of Ministers can suspend the membership. After suspension, the Member State in question can voluntarily withdraw. If this does not happen and the violations of fundamental principles of the CoE persist, the Committee of Ministers can terminate the membership.

Technically this process is not particularly difficult or lengthy. Moreover, the Committee of Ministers retains wide discretion as to how to interpret Article 3 and how to regulate the Article 8 procedure in practice. It seems that really serious breaches of human rights might justify the commencement of the process of suspension and termination, although Klein argues that 'in spite of many "serious violations" of [Article 3] principles having been committed by members, until today neither a suspension of the rights of representation nor an exclusion from the organization nor a voluntary withdrawal from the Council of

\footnotetext{
37 G de Vel, The Committee of Ministers of the Council of Europe (Council of Europe 1995) $49-50$.

38 Suspension of membership should not be confused with suspension of the right to representation at the PACE and the Committee of Ministers pursuant to art 9 of the Statute. In the latter case, the delegations of the suspended countries are only prevented from taking part in the work of Committee of Ministers and the PACE, while all other membership rights continue to exist. Suspension of the right to representation should also be distinguished from the suspension of the right to vote in the PACE which is even more limited. This is important because, as will be explained later, Russia's voting rights were suspended by the PACE; its suspension of right to representation was largely self-imposed. See K Dzehtsiarou and A Drzemczewski, 'Painful Relations between the Council of Europe and Russia' (EJIL: Talk! 28 September 2018) <https://www.ejiltalk.org/painful-relations-between-the-council-of-europe-andrussia/>; L Glas, The Assembly's Appeasement towards Russia, (Strasbourg Observers 27 September 2018) <https://strasbourgobservers.com/2018/09/27/the-assemblys-appeasementtowards-russia/>.
} 
the basis of a resolution of the Committee in the sense of Article $8 \mathrm{CoE}$ Statute has taken place'. ${ }^{39}$ This article argues that considerations should be given to a more rigorous application of Articles 7 and 8 of the Statute if States' behaviour undermines the normative foundations of the Strasbourg system.

\section{THE SIGNS OF CRISIS}

The integrity of the $\mathrm{CoE}$ is in peril. This integrity is threatened not by external forces but by the actions of the Member States of the Council itself. The threat concerns the values which underpin the Council system; the Statute of the Council refers to the values as inter alia 'the maintenance and further realisation of human rights and fundamental freedoms'. The manifestation of the threats can be seen in a series of crises that span Europe: the resurgence of xenophobia in many European States; the occupation of Crimea and support of a separatist movement in Eastern Ukraine and Georgia; and the actions of Turkey after the alleged military coup in 2016 which has led to severe human rights restrictions. In isolation, these challenges are not unprecedented but cumulatively they constitute significant threats to the Council system. ${ }^{40}$ This section argues that there are signs of crisis that justify the consideration of the use of the sanctions of last resort, namely suspension and expulsion.

\section{A. The Magnitude of the Present Crisis}

The CoE has had to deal with crises in its past. Greece withdrew from the CoE in the 1960s. The measures pursued by the United Kingdom in Northern Ireland led to an interstate complaint. ${ }^{41}$ Russia was admitted to the Council in 1996 but subsequently its voting rights were suspended in 2000-2001 as a result of the Second Chechen War. The reintroduction of voting rights in 2001 was based on Russia's perceived willingness to work for a solution 'in conformity with the CoE's standards and values'. ${ }^{42}$ Similarly, in the case of Turkey, the suspension of voting rights due to a failure to establish a democratic form of government in 1981 prompted a positive interaction by the Turkish Foreign Minister with the institutions of the CoE, resulting eventually in the lifting of

39 E Klein, 'Membership and Observer Status' in S Schmahl and M Breur (eds), The Council of Europe: Its Law and Politics (Oxford University Press 2017) 67.

${ }^{40}$ Ed Bates has identified a number of instances in which the Contracting Parties to the Convention have threatened to leave the convention system or acted in a manner that falls short of genuine collaboration with the Council of Europe, see E Bates, The Evolution of the European Convention on Human Rights (Oxford University Press 2010) 286-8.

41 Ireland $v$ the United Kingdom (18 January 1978) Series A no 25; for a more detailed account see B Dickson, The European Convention on Human Rights and the Conflict in Northern Ireland (Oxford University Press 2010).

42 'Conflict in the Chechen Republic - Recent Developments' Report Doc 8929 (20 January 2001). 
voting sanctions. ${ }^{43}$ In these cases, it was the fact that the Member States were perceived as positively engaging with the Council that ensured the situation did not escalate further.

These events show that the CoE lived through some significant social, political and military crises, however, it has never used its powers to expel members. ${ }^{44}$ Two key reasons distinguish the current crisis from past events. First, the current $\mathrm{CoE}$ consists of a high number of Member States ${ }^{45}$ it is more diverse than ever. This presents advantages and challenges to the organization. In the past, it can be argued that the core members shared certain democratic values. This, in a sense, simplifies the history of the organization; Turkey and Greece, for example, were members almost from the creation of the organization but both suffered military coups. Nonetheless, it is clear that the expansion of members means that there is less homogeneity to the CoE now than there was in the 1950s. The diverse heritages of current members, as well as the kaleidoscope of political constellations in those members, make it more difficult to discern an overarching agreement on core values. State accession to the $\mathrm{CoE}$ in the 1990s was often based on promises and potential rather than on concrete evidence of real progress in the new democracies. This approach in itself is not a violation of the Statute of the $\mathrm{CoE}$ as new members are unlikely to have attained the same democratic institutional framework at the point of accession as more established members. However, in that case, post-accession monitoring and the Council's ability to reverse its decision of accession are of crucial importance.

In 1995, the UK member of the PACE, David Atkinson, opined that '[w]e have been accepting into full membership counties which have not reached out standards, nor satisfied our qualifications. We have been tolerating the continuing failure of new members to honour their commitments, and we have turned a blind eye to old Member States for behaviour that we condemn in non-member countries' ${ }^{46}$ The accession procedures of, inter alia Russia, Ukraine, Romania, and Croatia were problematic and the benefit of the doubt was often given, sometimes over-optimistically, to the new members. ${ }^{47}$ In many cases this quick expansion, and accompanying optimism, became the root cause of the challenges that the Council is currently facing. It is incumbent on the PACE and Committee of Ministers to take measures to prevent crises

43 M Müftüler-Bac, Turkey's Relations with a Changing Europe (Manchester University Press 1997) 80-1.

44 Even in the case of Greece, formally the Greek authorities withdrew from the Council.

45 There are 47 Members in the CoE covering the vast majority of European States.

46 Quoted from D Huber, A Decade Which Made History: The Council of Europe 1989-1999 (Council of Europe 1999) 126.

47 For a helpful overview of accession of new members in the 1990 s, see P Leach, 'The Parliamentary Assembly of the Council of Europe' in S Schmahl and M Breuer (eds), The Council of Europe: Its Law and Policies (Oxford University Press 2017) 183-8; A Drzemczewski, 'Human Rights in Europe: An Insider's Views' (2017) EHRLR 134, 135-7. 
occurring, and remedy those which have occurred, as a result of the decisions of the 1990s.

The second reason is the depth of the crisis. What is new now, and what makes the issue existential, is the manner in which the developments such as failure to pay budgetary contributions or a disregard of the judgments of the ECtHR are being combined and used in order to justify a failure to collaborate or, one could even argue, a strong indication of an intention to obstruct the manner in which the CoE works. In the past, Member States either set their faces against compliance (such as in the Greek case) or appeared to collaborate proactively with the Council institutions (such as the UK or Turkey in the 1980s). What is becoming clear now, however, is that some of the apparent collaboration has failed to bear fruit. In order to appreciate the point here, it is necessary to sketch briefly the areas in which this lack of collaboration has occurred.

\section{B. Failure to Cooperate with the Council of Europe}

\section{Reaction of the PACE to the occupation of Crimea}

An international organization can fulfil its aims when its members are willing to collaborate. Although some organizations have severe sanctions for the lack of engagement, ultimately it is voluntary collaboration that makes an international organization successful. A blatant failure to engage with the requirements of the organization undermines its reputation and weakens its legitimacy. For instance, in 2015 the PACE adopted a resolution in which it demanded that Russia withdraw from Crimea and stop supporting separatists in Eastern Ukraine; this was to no effect. ${ }^{48}$ Such a resolution is not binding and does not create a direct international obligation for Russia. ${ }^{49}$ However, the lack of cooperation shows the unwillingness of a Member State to participate in the work of an international organization. Moreover, the situation concerned military aggression of one member of the Council against another member, which demonstrates the Council's inability to prevent war. As a result of the negative reaction of the PACE to military occupation, Russia stopped collaborating with it. As a reaction to the subsequent crisis in Ukraine, the PACE suspended some rights of the Russian Delegation including the right

\footnotetext{
48 See Res 1988 (2014) <http://assembly.coe.int/nw/xml/XRef/Xref-XML2HTML-en.asp? fileid=20873\&lang $=$ en $>$.

49 The fact that resolutions are soft-law mechanisms does not mean that they have no legal value. For instance, the European Court of Human Rights uses them in its reasoning. See eg El-Masri v the former Yugoslav Republic of Macedonia [GC], no 39630/09, ECHR 2012, para 99; Mozer v the Republic of Moldova and Russia [GC], no 11138/10, ECHR 2016, para 67; A and Others $v$ the United Kingdom [GC], no 3455/05, ECHR 2009, para 106.
} 
to vote in $2014^{50}$ and $2015 .{ }^{51}$ The Russian Delegation was not, however, expelled from the PACE. The members of the delegation could still participate in certain areas of work of the PACE. The PACE did not revoke the credentials of the Russian Delegation in 2015, in other words the rights to representation were not suspended. Pursuant to its internal procedures, the PACE has to ratify the credential of delegations from all Member States annually. Since Russia failed to comply with the resolution of the PACE in 2015, there was a probability the PACE might not ratify the credentials of the Russian Delegation in 2016. In order to avoid this potential humiliation, the Russian authorities decided not to submit these credentials for ratification at all which effectively led to a self-induced suspension of representation in the PACE. ${ }^{52}$ The credentials were not presented in 2017, 2018 and again in 2019. It means that the Russian authorities stopped participating in the PACE of their own volition. ${ }^{53}$

\section{Failure to fulfil financial obligations}

In order to fulfil its statutory aims the $\mathrm{CoE}$ needs financial resources. Its budget is formed from the contributions of the Member States; this is calculated through a special formula which takes into account the population and GDP of the country concerned. In 2018, the budget of the CoE was slightly over $€ 466$ million of which the ordinary budget ${ }^{54}$ is approximately $€ 260$ million. ${ }^{55}$ To compare, the annual budget of the Court of Justice of the European Union (CJEU) is almost $€ 400$ million. ${ }^{56}$ In contrast, the operation of the ECtHR, including the execution of its judgments, amounts to almost $€ 78$ million or less than a quarter of its EU counterpart. ${ }^{57}$ Comparatively speaking, therefore, the budget of the $\mathrm{CoE}$ seems quite limited. Notwithstanding this

\footnotetext{
50 'Reconsideration on Substantive Grounds of the Previously Ratified Credentials of the Russian Delegation' Res 1990 (2014) PACE. <http://website-pace.net/documents/10643/ 110596/ 20140410-Resolution1990-EN.pdf/57ba4bca-8f5f-4b0a-8258-66ca26f7117b $>2$.

51 'Citing Crimea, PACE Suspends Voting Rights of Russian Delegation and Excludes It from Leading Bodies' (PACE News, 10 April 2014) < http://assembly.coe.int/nw/xml/News/News-ViewEN.asp? newsid $=4982 \&$ cat $=8>$.

52 'President Regrets Russian Parliament's Decision Not to Participate in the Work of the Assembly in 2016' (PACE News, 19 January 2016) <http://www.assembly.coe.int/nw/xml/News/ News-View-EN.asp?newsid $=5980 \&$ lang $=2 \&$ cat $=>$.

53 A special ad hoc committee of the PACE was set to establish a dialogue with Russia on that matter. However, at the moment of writing no tangible outcome of this dialogue was reported (February 2019). 'Kuleba Says ad hoc Committee to Discuss Proposals on Russia's Return to PACE on March 16' (Kiev Post 2 February 2018) <https://www.kyivpost.com/russia/kulebasays-ad-hoc-committee-discuss-proposals-russias-return-pace-march-16.html>. See also Statement of the State Duma, 'On the Situation around Russian Participation in the Parliamentary Assembly of the Council of Europe' <http://duma.gov.ru/en/news/29465/>.

54 S Schmahl, 'Budget and Finances' in S Schmahl and M Breur (eds), The Council of Europe. Its Law and Politics (Oxford University Press 2017) 122-3.

55 'CoE Programme and Budget 2018-2019'<https://rm.coe.int/16807761cd>.

56 The difference between the overall budget and ordinary budget is provided by voluntary contributions, programmes financed by the European Union etc.

57 ibid 21.
} 
relative parsimony, in recent years some Member States have adopted a practice of financial recalcitrance towards the CoE. They have failed to pay their contributions to the budget of the organization in retaliation for decisions that the $\mathrm{CoE}$ has taken.

In 2017, Russia failed to pay two-thirds of its contribution to the ordinary budget of the CoE. They justified it by references to the lack of participation of the Russian Delegation in the PACE which was, as described above, effectively self-inflicted. This financial pressure continued in 2018, when Russia refused to pay $€ 11$ million due on 28 February. ${ }^{58}$ These actions fall short of the standard of 'sincere collaboration' established under Article 3 of the Statute of the CoE.

The CoE cannot allow fiscal intransigence to undermine the normative structure of the Strasbourg system. Engel has noted that Russia's unwillingness to pay its bills also threatens the job security of employees of the Council; ${ }^{59}$ these employees may choose to pursue careers with other institutions if such uncertainty continues. The Statute of the CoE envisages a sanction for failure to comply with the States' financial obligations. According to Article 9, the Committee of Ministers of the CoE may suspend the right of representation on the Committee and on the PACE of a member which has failed to fulfil its financial obligations. In the case of Russia, the CoE can suspend the right of representation on the Committee, as Russia's representation in the PACE is de facto suspended. If a Member State does not fulfil its obligations persistently than it can be requested to withdraw from the organization. ${ }^{60}$

Another example of using financial instruments to put pressure on the $\mathrm{CoE}$ is Turkey. In 2016, the Turkish authorities decided to become a major contributor to the CoE. ${ }^{61}$ Major contributors are the biggest countries in Europe: France, Germany, Italy, Russia, the United Kingdom and, since 2016, Turkey. They each payed over ten per cent of the Council's budget. ${ }^{62}$ In 2017, Turkey revoked its status as a major contributor of the $\mathrm{CoE}$ in response to increased demands directed to the Turkish authorities to stop widespread human rights violations $^{63}$ and the award of the Václav Havel Human Rights prize to Murat

\footnotetext{
58 'Russia Withholds Payments to the Council of Europe' (Deutsche Welle 1 March 2018) $<$ http://www.dw.com/en/russia-withholds-payments-to-the-council-of-europe/a-42792673>.

59 NP Engel, 'Russland teste das Rückgrad des Europarates' (2017) Europäische Grundrechte Zeitschrift 720, 721.

${ }^{60}$ F Benoit-Rohmer and H Klebes, Council of Europe Law: Towards a Pan-European Legal Area (Council of Europe 2005) 44.

61 'PACE Welcomes Turkish Authorities' Proposal to Become a Major Contributor to the CoE Budget' (PACE news, 21 April 2015) <http://assembly.coe.int/nw/xml/News/News-View-EN.asp? newsid $=5547 \&$ lang $=2 \&$ cat $=>$.

${ }^{6}$ S Schmahl, 'Budget and Finances' in S Schmahl and M Breur (eds), The Council of Europe: Its Law and Politics (Oxford University Press 2017) 110.

${ }^{63}$ Resolution 2156 (2017) 'The Functioning of Democratic Institutions in Turkey' <http:// semantic-pace.net/tools/pdf.aspx?doc=aHR0cDovL2Fzc2VtYmx5LmNvZS5pbnQvbncveG1sL1 hSZWYvWDJILURXLWV4dHIuYXNwP2ZpbGVpZD0yMzY2NSZsYW5nPUVO\&xsl=aHR0
} 
Aslan. ${ }^{64}$ Although Turkey continues contributing to the budget, its contribution has been substantively reduced. Due to these actions the CoE noted 'a cumulative financial risk of $€ 42.65$ million for the first time in its history' ${ }^{65}$ Unlike the case of Russia, Turkey was free to withdraw its support, as it was voluntary, but the manner in which it was done seems to run contrary to the duty of sincere cooperation. In the face of Russian and Turkish financial abstinence it seems likely that the final result will be the loss of jobs and the suspension of some human rights programmes administered by the CoE.

\section{Allegations of corruption}

Finally, corruption allegations were recently investigated against some members of the PACE. Member States that use corrupt methods cannot be considered as collaborating properly and genuinely within the framework of the CoE. The Independent Investigation Body of the PACE investigated a number of countries ${ }^{66}$ but the main part of the report relates to the allegation of corruption received from Azerbaijan. The Investigation Body opined that as a result of corruption the PACE softened its position in respect of human rights violations in Azerbaijan. ${ }^{67}$ According to the report '[m]any witnesses heard by the Investigation Body also had the impression that gifts and different forms of benefits, in some instances even money, had played a role in the decision-making processes concerning Azerbaijan'. ${ }^{68}$ In considering how to respond to such methods, it may be tempting to conclude that it is the isolated behaviour of a small number of individuals. This temptation must, however, be interrogated contextually to determine whether it is simply a limited number of people, or part of a larger pattern of behaviour of that Member State's interaction with the CoE. In the latter case, the CoE should be prepared to consider the allegations holistically and act accordingly.

cDovL3NlbWFudGljcGFjZS5uZXQvWHNsdC9QZGYvWFJIZi1XRC1BVC1YTUwyUERGL nhzbA $==\& x$ sltparams $=Z m l s Z W l k P T I z N j Y 1>$.

${ }^{64}$ Murat Aslan is considered a member of the organization that was allegedly behind the coup attempt in $2016<\mathrm{http} / / / \mathrm{www}$.hurriyetdailynews.com/turkey-no-longer-major-council-of-europedonor-minister-122219>.

65 'Modification of the Assembly's Rules of Procedure: The Impact of the Budgetary Crisis on the List of Working Languages of the Assembly' $<$ http://assembly.coe.int/nw/xml/XRef/XrefXML2HTML-en.asp?fileid=24545\&lang=en $>$. $\quad{ }_{67}$ Armenia, Russia, Ukraine and others.

67 'Report of the Independent Investigation Body on the Allegations of Corruption within the Parliamentary Assembly' (Council of Europe, 15 April 2018) <http://assembly.coe.int/ Communication/IBAC/IBAC-GIAC-Report-EN.pdf> 22-3.

68 '[A] PACE secretariat member gave oral evidence to the Investigation Body explaining that in 2005 she had had lunch with several of her colleagues and Mr Gross. On that occasion Mr Gross had said that he knew from a very certain source that the then head of the office in Baku, a CoE staff member, had received a EUR 100,000 bribe from the Azerbaijani authorities. However, there had been no reaction to this in the COE, as nobody had taken this allegation seriously'. ibid 23. 


\section{Creating Domestic Legal Obstacles for Execution of Judgments of the European Court of Human Rights}

The ECHR and the Strasbourg Court are 'the crown jewel' of the CoE. They are the essential parts of the Council and the key elements of the Strasbourg system of human rights protection. Failure to cooperate with the ECtHR effectively means failure to collaborate with the $\mathrm{CoE}$. The recent developments in Russia in this regard are particularly troubling. Russia has threatened to denounce the ECHR because of the belief that the ECtHR delivers judgments adverse to Russian national interests; such a threat is in conflict with a commitment to collaborate in the area of human rights protection and can be seen as an attempt to influence the outcomes of cases in a manner more amenable to Russian interests. ${ }^{69}$ The lack of cooperation of Russia with the PACE has led to the incredible suggestion made by the Speaker of the Russian Senate that the judges of the ECtHR who were elected after the selfinduced departure of the Russian Delegation from the PACE should not give judgments against Russia. On this view, if at least one such judge is on the bench then these judgments are illegitimate and should not be executed. ${ }^{70}$ Legally speaking, this is clearly incorrect as the Convention only indicates that the judges should be elected by the PACE; ${ }^{71}$ it does not state the exact composition of the PACE. All elections were conducted in accordance with the internal procedures of the PACE and therefore the lack of participation of Russia does not negate the legitimacy of the Court. Moreover, the argument is further flawed as it would mean that a country which intended to commit a systemic violation of human rights could withdraw their delegation and subsequently argue that judgments which were adverse to them were invalid.

In recent years, attempts have been made to justify the failure to implement the judgments of the ECtHR by reference to the provisions of national law. The issue manifests itself in the following manner: in cases of conflict between the requirements of the ECtHR and national constitutions, national courts may choose to follow their own constitutional provisions rather than the judgments of the ECtHR. This approach is highly problematic because it is in

69 A Griffin, 'Russia Could Withdraw from European Convention on Human Rights, State News Agency RIA Reports' (Independent 1 March 2018) < http://www.independent.co.uk/news/world/ europe/russia-echr-human-rights-european-convention-putin-kremlin-eu-a8234086.html>. See also A Matta and A Mazmanyan, 'Russia: In Quest for a European Identity' in P Popelier, S Lambrecht and K Lemmens (eds), Criticism of the European Court of Human Rights (Intersentia 2016) 495-6.

${ }^{70}$ The Speaker of the Russian Senate claimed that Russia will not recognize the judgments of the ECtHR. Матвиенко заявила об отказе России признавать решения ЕСПЧ из-за ПАСЕ, РБК, 9 October 2017, <https://www.rbc.ru/politics/09/10/2017/59db7cdc9a79470249c79eba>; see also Б. Тузмухамедов, Кто судит Россию в Страсбурге. ПАСЕ избирает служителей Фемиды в отсутствие голоса нашей страны, Независимая Газета (13 February 2018) <http://www.ng. ru/vision/2018-02-13/2_7171_strasburg.html>.

71 Art 22 ECHR. 
contravention of Article 27 of the Vienna Convention on the Law of Treaties. ${ }^{72}$ International obligations continue to exist even if the national law says otherwise and the State in question is responsible for their violations. ${ }^{73}$ In the past if such conflicts arose the apex courts tried to solve them through the means of interpretation. ${ }^{74}$ More recent activities in this area are, however, the distorted mirror image of the previous alignment: States are using the legal basis of a constitutional system in order to elide the political lack of will to comply with ECtHR judgments with which the State disagrees.

The example of Russia is of interest here. On 31 July 2014, the ECtHR awarded the applicant in the case of Yukos $v$ Russia almost $€ 2$ billion of just satisfaction. ${ }^{75}$ This event triggered the creation of a legal instrument that would allow Russia to avoid compliance with this judgment of the ECtHR. ${ }^{76}$ The first step for creation of this system was a decision of the Russian Constitutional Court of 14 July 2015, in which it posited that judgments of the ECtHR should be executed by the national authorities unless the execution would lead to breaches of the foundational principles and norms of the Russian Constitution. ${ }^{77}$ This decision was quickly followed by the amendment to the law of the Constitutional Court that allowed it to consider if a judgment of the ECtHR, in fact, violates the principles and norms of the Russian Constitution. Effectively the Russian Constitutional Court became an

72 Art 27 VCLT states that a party may not invoke the provisions of its internal law as justification for its failure to perform a treaty.

${ }^{73}$ G Martinico, 'Is the European Convention Going to Be "Supreme"? A ComparativeConstitutional Overview of ECHR and EU Law before National Courts' (2012) 23 EJIL 401, 422.

74 See Görgülü 2 BvR 1481/04 (14 October 2004) BVerfGE 111, 307 (Ger); for more examples see K Dzehtsiarou and N Mavronicola, 'Relation of Constitutional Courts / Supreme Courts to the ECtHR' Max Planck Encyclopaedia of Comparative Constitutional Law, <http://oxcon.ouplaw. com/view/10.1093/law-mpeccol/law-mpeccol-e572>.

${ }_{75}$ OAO Neftyanaya Kompaniya Yukos v Russia (just satisfaction), no 14902/04 (31 July 2014).

76 For a more in-depth analysis of the Yukos case see, K Dzehtsiarou and F Fontanelli, 'Unprincipled Disobedience to International Decisions: A Primer from the Russian Constitutional Court' (2018) European Yearbook of Human Rights 319; B Bowring 'Russia's Cases in the ECtHR and the Question of Implementation' in L Mälksoo and W Benedek (eds), Russia and the European Court of Human Rights (Cambridge University Press 2017); I Marchuck and M Aksenova, 'The Tale of Yukos and of the Russian Constitutional Court's Rebellion against the European Court of Human Rights' (Osservatorio Costituzionale, 6 April 2017) <https:/www.osservatorioaic.it/ images/rivista/pdf/Marchuck-Aksenova\%20Definitivo.pdf>.

77 Decision N 21-П Verification of Constitutionality of Art 1 of the Federal Law 'On Ratification of the Convention for the Protection of Human Rights and Fundamental Freedoms and Its Protocols', Sections 1 and 2 of Art 32 of the Federal Law 'On International Treaties of the Russian Federation', Sections 1 and 4 of Art 11, Subsection 4 of Section 4 of Art 392 of the Civil Procedural Code of the Russian Federation', Sections 1 and 4 of Art 13, Subsection 4 of Section 3 of Art 311 of the Arbitration Procedural Code of the Russian Federation, Sections 1 and 4 of Art 15, Subsection 4 of Section 1 of Art 350 of the Administrative Court Proceedings Code of the Russian Federation, and Subsection 2 of Section 4 of Art 413 of the Criminal Procedural Code of the Russian Federation in Relation to the request of the Group of the Members of State Duma (Parliament) (14 July 2015). See also Dzehtsiarou and Mavronicola (n 74). For in-depth analysis see L Mälksoo, 'Russia's Constitutional Court Defies the European Court of Human Rights. Constitutional Court of the Russian Federation Judgment of 14 July 2015, No 21-П/2015' (2016) 12 EuConst 377. 
appeal tribunal for the judgments of the ECtHR where the Russian authorities could now apply to strip the ECtHR judgment of any legal effects in the Russian domestic legal order. As a result, the Russian authorities can pick and choose those judgments they are willing to execute. The Russian Constitutional Court first adjudicated on these newly obtained competences in a case of Anchugov and Gladkov $v$ Russia concerning the blanket disenfranchisement of all prisoners which is provided in the Constitution of Russia. It declared that at least some aspects of that ECtHR judgment were impossible to execute. ${ }^{78} \mathrm{On}$ 19 January 2017, the Russian Constitutional Court also declared the judgment in Yukos unexecutable. ${ }^{79}$

The judgment of the Russian Constitutional Court in Yukos stands as an example of the State's avoidance of a judgment of the ECtHR which involves major monetary compensation to the applicant. Nothing in the Russian Constitution directly prohibits payment of just satisfaction. Unlike other European national courts ${ }^{80}$ that tried to find a way to reconcile the case law of the ECtHR and national constitutional order, the Russian Constitutional Court selected a direct confrontation, manufacturing a new line of jurisprudence in order to avoid compliance with the State's obligations under the ECHR. ${ }^{81}$

The judgments of the Russian Constitutional Court in Anchugov and Gladkov and in Yukos limit the ability of the national authorities to execute the ECtHR judgments; even if there was a political will to comply, now they might be prevented from doing so by the Constitutional Court. ${ }^{82}$ On the one hand, these decisions do not alter the international obligations of Russia and, according to Article 46 of the ECHR, it needs to implement both judgments. On the other hand, this can hardly be done on the national level because the decisions of the Constitutional Court prohibit enforcement. ${ }^{83}$ This behaviour

\footnotetext{
78 'Possibility of Execution of the Judgment of the European Court of Human Rights in the Case of Anchugov and Gladkov v Russia' < http://doc.ksrf.ru/decision/KSRFDecision230222.pdf> (in Russian). K Dzehtsiarou, S Golubok and M Timofeev, 'The Russian Response to the Prisoner Voting Judgment' (ECHRblog, 29 April 2016) < http://echrblog.blogspot.co.uk/2016/04/therussian-response-to-prisoner-voting.html>.

79 Judgment of 19 January 2017 No $1-\Pi / 2017$ in the case concerning the resolution of the question of the possibility to execute in accordance with the Constitution of the Russian Federation the Judgment of the European Court of Human Rights of 31 July 2014 in the case of OAO Neftyanaya Kompaniya Yukos v Russia in connection with the request of the Ministry of Justice of the Russian Federation. A courtesy translation is available on the website of the Russian Constitutional Court, and all quotations will be drawn from it, unless otherwise noted $<$ http://www.ksrf.ru/en/Decision/Judgments/Documents/2017_January_19_1-P.pdf $>$.

${ }^{80}$ For example, the German Constitutional Court in Gorgulu, Italian Constitutional Court and UK Supreme Court. Dzehtsiarou and Mavronicola (n 74).

${ }_{81}$ For a more detailed analysis of the Yukos case see, Dzehtsiarou and Fontanelli (n 76).

82 It remains to be seen if the recent award against Gazprom by the Arbitration Institute of the Stockholm Chamber of Commerce for USD2.56 billion to Naftogaz will be complied with, or if the problem is regarded as being unique to the ECHR system.

${ }^{83}$ For more detail see, Final Opinion on the Amendments to the Federal Constitutional Law on the Constitutional Court $<$ http://www.venice.coe.int/webforms/documents/default.aspx? pdffile $=$ CDL-AD(2016)016-e $>$ para 34 .
} 
of the State leads not only to difficult legal questions involving conflict of laws but also shows a lack of commitment to the ideals of the rule of law and human rights which are the founding pillars of the CoE. ${ }^{84}$ This behaviour can become contagious as Azerbaijan for example is considering introducing a similar institutionalized system of disobedience with ECtHR judgments. ${ }^{85}$

\section{Failure to Execute Individual Judgments or Lack of Engagement with the Committee of Ministers}

Creating legal obstacles to execution discussed in the previous section is a systemic challenge; the respondent State builds a juristic pathway to preemptively justify its (anticipated) failure to execute judgments of the ECtHR. Some Member States do not resort to such sophisticated schemes and merely fail to implement the judgments of the Court. Of course, a single failure to implement a judgment of the ECtHR cannot justify expulsion from the Convention. However, persistent, gross or systematic avoidance of the Strasbourg acquis should be taken seriously.

The ECHR system is based on the idea that a finding of a violation of the Convention by the ECtHR should be rectified. Three types of remedies are available: first, just satisfaction for pecuniary and non-pecuniary damage, second, individual measures and finally, general measures. The Committee of Ministers closes the execution when all necessary remedies are effectuated. Azerbaijan has the worst record of closed cases by the Committee of Ministers. Only 3 out of 206 were fully executed by the Azerbaijani government (less than 2 per cent) making it the worst country in terms of execution of ECtHR judgments. ${ }^{86}$ For Russia, the Committee of Ministers closed 743 cases out of 2492 (less than 30 per cent). ${ }^{87}$ The record from Turkey is slightly better-2568 closed cases out of 3819 (less than 70 per cent). ${ }^{88}$ This section will provide a snapshot of failures to effectuate focusing on each of these three types of remedies.

Just satisfaction is the 'simplest' aspect of execution; the respondent State needs to pay monetary compensation to the injured party. Notwithstanding this simplicity, countries do not necessarily comply with this requirement, eg Turkey. Unlike the Russian juristic method of avoidance in the case of Yukos, Turkey did not create a sophisticated system for the avoidance of

\footnotetext{
${ }^{84}$ See E Klein 'Membership and Observer Status' in S Schmahl and M Breur (eds), The Council of Europe: Its Law and Politics (Oxford University Press 2017) 46.

85 'In Azerbaijan, a Draft Constitutional Law, along the lines of the Russian Constitutional Court law, has been introduced by one of the members of parliament during the 2016 spring session of the National Assembly.' <https://www.coe.int/en/web/commissioner/-/non-implementation-of-thecourt-s-judgments-our-shared-responsibility?desktop=true $>$. This law has not been yet adopted.

86 'Azerbaijan, Country Factsheet.' Committee of Ministers. < https://rm.coe.int/168070973e>.

87 'Russian Federation, Country Factsheet.' Committee of Ministers. <https://rm.coe.int/ russian-factsheet/1680764748>. $<$ https://rm.coe.int/1680709767>.
} 
compliance with the judgment of the ECtHR. Instead, the government simply declared that it would not pay just satisfaction in the interstate case of Cyprus $v$ Turkey. ${ }^{89}$ At the time of writing (January 2019) this issue has not been resolved, although the judgment on just satisfaction was delivered on 12 May 2014. Normally, the payment of just satisfaction is done within three months. ${ }^{90}$

Under the rubric of individual measures, the Committee of Ministers of the $\mathrm{CoE}$ demands that the respondent State remedy the situation of the victim of a human rights violation. An example here is the problematic case of Ilgar Mammadov $v$ Azerbaijan. The applicant was an opposition politician in Azerbaijan who spent more than five years in prison. The ECtHR found a violation of Article 18 in conjunction with Article 5, namely that his detention was for his political activities and not for the crimes he was accused of. The Committee of Ministers urged the Azerbaijani authorities to release the applicant on a number of occasions. ${ }^{91}$ In November 2017 and pending the implementation of the first judgment, the Fifth Section found a further breach of Article 6 in Ilgar Mammadov v Azerbaijan (No 2)..$^{92}$ In October 2017, the Committee of Ministers indicated to Azerbaijani authorities its intention to invoke the Article 46(4) procedure for failure to comply with the ruling in the first Mammadov case. ${ }^{93}$ In December 2017, and in light of the inability of the Azerbaijani authorities to offer a compelling justification for their failure to comply, the Committee of Ministers referred the question back to the ECtHR. ${ }^{94}$ Significantly, the Article 46(4) procedure requires a two-thirds majority of the Committee of Ministers in order to refer the matter-the fact that this high threshold was reached indicates widespread dissatisfaction with the behaviour of the Azerbaijani authorities in this case. ${ }^{95}$ On 13 August 2018, Mammadov was conditionally released from prison ${ }^{96}$ but the ECtHR will nevertheless have to decide if the judgment was properly executed as the Committee of Ministers did not revoke its request under 46(4). Although the effectiveness of this procedure is questionable, ${ }^{97}$ the

${ }^{89}$ Cyprus v Turkey (just satisfaction) [GC], no 25781/94, ECHR 2014. The response of Turkey: 'Turkey Won't Pay Cyprus Despite Decision in Strasbourg' (Deutsche Welle, 13 May 2014) <http:// www.dw.com/en/turkey-wont-pay-cyprus-despite-decision-in-strasbourg/a-17631966>.

90 Although we appreciate the fact that this is a complex case a four-year delay cannot be considered adequate and proportionate.

91 Ilgar Mammadov v Azerbaijan, no 15172/13 (22 May 2014).

92 Ilgar Mammadov v Azerbaijan (No 2), no 919/15 (16 November 2017).

93 For more details on Art 46(4) see de Londras and Dzehtsiarou (n 36).

94 'Interim Resolution CM/ResDH(2017)429: Execution of the Judgment of the European Court of Human Rights Ilgar Mammadov against Azerbaijan'<https://search.coe.int/cm/Pages/ result_details.aspx?ObjectID $=090000168076 \mathrm{fl} \mathrm{fd}>$.

95 "Call for referral of Mammadov case to the Strasbourg Court "as soon as possible" on question of whether Azerbaijan has failed to abide by the judgment' (PACE news, 13 October 2017) <http:// www.assembly.coe.int/nw/xml/News/News-View-EN.asp?newsid=6837\&lang=2\&cat=>.

96 'Azerbaijani Opposition Leader Mammadov Released from Prison' (RFE/RL, 13 August 2018) < https://www.rferl.org/a/azerbaijani-opposition-leader-mammadov-released-prison/ 29430183.html>.

97 de Londras and Dzehtsiarou (n 36). 
decision of the ECtHR about the failure to execute its judgment can act as a justification for triggering the procedure for suspension of $\mathrm{CoE}$ membership.

Finally, the most complex part of execution of judgments-general measures. These measures must ensure that the violation identified in the judgment does not happen again. General measures are inherently problematic irrespective of whether the respondent States genuinely wish to comply with the judgments of the ECtHR. The measures may require timeconsuming legislative reforms and these reforms can be complex in a pluralist democracy. ${ }^{98}$ Notwithstanding these issues, there are clear situations when the Contracting Parties are perceived to undermine the reputation and authority of the ECtHR by not implementing the judgments of the ECtHR. The case of Hirst No $2 v U K$ is an appropriate example here. ${ }^{99}$ In 2005, the ECtHR decided that a blanket ban on prisoner voting in the UK violates the ECHR. Between 2005 and 2017, despite the efforts of the Committee of Ministers and the Court, the judgment was not implemented by UK authorities. ${ }^{100}$ In 2017, the UK Government indicated that it would change the administrative guidance governing prison rules in order to allow prisoners on short-term release or those serving their sentence via home detention curfew the right to vote. In December 2017, at the same meeting where the Committee of Ministers resolved to pursue the Article 46 case against Azerbaijan, the Committee of Ministers concluded the proposed changes 'appear to be an adequate response' to the cases. ${ }^{101}$

One can argue that an isolated incident such as the Hirst case is not a compelling reason to initiate a disciplinary action against a Member State; this would serve to entrench an intransigent approach to the Convention which would merely thin the ranks of Member States. While a single incident must be analysed proportionately, it is also clear that a failure to engage in the dialogue and cooperation with the institutions can reach a scale far removed from an isolated incident. In this regard, a persistent failure to engage with the institutions in relation to a single judgment may eventually become problematic, although this must be viewed contextually. This failure serves to undermine the collaborative framework outlined in Article 1 of the Statute of the CoE. In this regard, it is necessary to take a holistic approach to the question of

98 These reforms can be politically difficult (enacting a piece of controversial legislation) or merely financially burdensome (for example building a new prison).

${ }_{99}$ Hirst $v$ the United Kingdom (no 2) [GC], no 74025/01, ECHR 2005-IX.

100 Greens and MT v the United Kingdom, nos 60041/08 and 60054/08, ECHR 2010, Interim Resolution CM/ResDH(2015)251, K Dzehtsiarou, 'Prisoner Voting Saga: Reasons for Challenges' in H Hardman and B Dickson, Electoral Rights in Europe (Routledge, 2017), K Dzehtsiarou, 'Prisoner Voting and Power Struggle: A Never-Ending Story?' (Verfassungsblog, 30 October 2017) <https://verfassungsblog.de/prisoner-voting-and-power-struggle-a-neverending-story/>.

101 '1302nd meeting, 5-7 December 2017 (DH)' $<$ https://search.coe.int/cm/pages/result_details. aspx? objectid $=090000168076465 \mathrm{~d}>$; the decision of the Committee of Ministers: $<$ https://search. coe.int $/ \mathrm{cm} /$ Pages/result_details.aspx?ObjectID=090000168076d59d $>$. 
suspension of membership. Relevant considerations would, however, include those outlined in this section, ie a failure to comply with budgetary obligations, the creation of national obstacles to execution of the ECtHR judgments, and failure to implement individual judgments. The means by which a suspension can occur will now be briefly outlined.

\section{CALCULATIONS FOR SUSPENSION AND EXPULSION}

The Statute of the CoE provides a number of ways to sanction its members for not complying with its statutory aims. This section suggests how these sanctions can be interpreted and applied. The sanction mechanisms should be used with particular regard to the operation of the CoE system as a whole. The CoE is a regional system which aims to protect human rights, democracy and the rule of law; these features of the CoE should inform the interpretation of Articles 7 and 8 of the CoE Statute.

We do not aim to predict the outcomes or likelihood of these sanctions, although game theory provides a rational explanation of when and how sanctions to States that are failing to cooperate in multilateral context can be applied, ${ }^{102}$ nor do we do elaborate a formulaic approach. Instead, we limit ourselves to offering some rough calculations that the statutory bodies of the Council can use in deciding whether to apply harsh sanctions such as suspension and expulsion, while acknowledging that the contextual nature of any such calculation makes the expression of binary choices difficult in such circumstances.

In this section we will explore two sets of considerations which can inform a decision about the necessity to deploy disciplinary mechanisms against a State that persistently, systematically or grossly undermines democracy, human rights and the rule of law. These should not be taken as exhaustive, but provide a means to weigh up the major factors that can influence such a decision. The calculations deal with the following two broad areas:

1. Legitimacy, effectiveness and reputation

2. Protection of human rights.

\section{A. Legitimacy, Effectiveness and Reputation}

The effectiveness of an international organization depends, to some degree, on its reputation. ${ }^{103}$ This reputation is based on how successful a particular

\footnotetext{
102 See for example, A Thompson, 'The Rational Enforcement of International Law: Solving the Sanctioners' Dilemma' (2009) International Theory 307.

103 Generally on the concept and definition of reputation see JC Sharman, 'Rationalist and Constructivist Perspectives on Reputation' (2007) 55 Political Studies 20; see also S Dothan, Reputation and Judicial Tactics: A Theory of National and International Courts (Cambridge University Press 2014) for a discussion of the value of reputation in judicial decision-making.
} 
organization is in fulfilling its aims. This argument is, to a certain extent, circular: success begets success, and failure begets failure. Undoubtedly, expulsion of a Member State would damage the reputation of an international organization. Expulsion means that the organization has failed in facilitating collaboration with the State concerned; it also failed to 'domesticate' it. In the case of the CoE, the moral stance of Europe as a family of States might be undermined if one of its members is expelled. For example, in his interview with The Financial Times the Secretary General of the CoE made the following remarks concerning a possible Russian expulsion: '[i]t will be a negative development for Europe, because we will have a Europe without Russia. It would be a big step back for Europe.' 104 This moral stance cannot, however, justify keeping a particular Member State within the organization because it is European. If that were the case, the idea of effective voluntary collaboration within the organs of the $\mathrm{CoE}$ would become meaningless. Here, we suggest that the following calculations should be explored when the question of suspension or expulsion is raised - if the presence of a Member State in an organization damages its reputation more than expulsion, then this is an argument in favour of the expulsion of this State. We suggest that three sets of considerations should be taken into account for this calculation.

\section{Is expulsion of a Member State less damaging for the CoE than its continuing membership?}

Does the mere presence in the organization of a particular Member States further the aims of this organization? The aim of the $\mathrm{CoE}$ is to enhance the unity between the Member States through their commitment to democracy, human rights and the rule of law. If a Member State becomes less democratic and less committed to human rights, then the $\mathrm{CoE}$ is failing in its core function. While it is unfair to blame the international organization for the decisions of Member States, which are often motivated by domestic concerns, it is necessary to consider the reaction of the international organization to the degradation of democracy and human rights within the Member States.

In some countries the human rights situation has deteriorated in recent years. In Turkey the government violently supressed an alleged State coup. While the situation in Turkey was very serious, the $\mathrm{CoE}$ has been moderate in its reaction to it. ${ }^{105}$ In 2008, Russia conducted a military operation in Georgia and in 2014,

\footnotetext{
104 'Russia tests CoE in push to regain vote' (Financial Times, 26 November 2017) $<$ https:// www.ft.com/content/3cccaf92-d12c-11e7-b781-794ce08b24dc>. See also 'Secretary General to PACE: Russian People Would Suffer Most if Russia Leaves the Council of Europe' (CoE News, 22 January 2019) <https://www.coe.int/en/web/portal/-/secretary-general-to-pace-russian-peoplewould-suffer-most-if-russia-leaves-the-council-of-europe>.

${ }^{105}$ Both the political and the judicial organs of the $\mathrm{CoE}$ were criticized for their passive reaction to the crisis in Turkey. See K Koroteev and S Golubok, 'Erdogan's Unexpected Ally' (OpenDemocracy, 5 September 2016) <https://www.opendemocracy.net/can-europe-make-it/ kirill-koroteev-sergey-golubok/erdogan-s-unexpected-ally>. E Turkut, 'Has the European Court
} 
Russia occupied the Crimean Peninsula - a part of the territory of another Member State of the CoE (Ukraine) - and, although on that occasion Russia lost its voting and some other rights in the PACE, ${ }^{106}$ it still remains a member of the CoE. As Lauri Mälksoo concludes 'instead of the desired approximation with liberal democracies in Western Europe, Russia's membership in the CoE and acceptance of the jurisdiction of the ECtHR have not been able to prevent a backlash in terms of democracy and human rights in the country' ${ }^{107}$ In Azerbaijan it is widely accepted that there are political prisoners, ${ }^{108}$ the State does not always implement the judgments of the ECtHR, ${ }^{109}$ and yet Azerbaijan is a full member of the CoE. This raises the question of whether the constant, and increasing, reputation losses from the States that fail to comply with human rights on a systematic level outweigh a moral commitment to Europe as a family of States.

An argument that might explain the CoE's reluctance to resort to suspension and expulsion is that the membership can assist the resolution of conflict situations. ${ }^{110}$ The CoE, for example, can provide an arena for negotiations between parties to a conflict. However, the conflicting parties need to engage with the $\mathrm{CoE}$ in their efforts to resolve the conflict. If the conflicting parties genuinely engage, it would be appropriate for the $\mathrm{CoE}$ to retain these Member States within the organization in order to complete the resolution of the conflict. If such engagement is purely formal or, even worse, absent then what can only ultimately be fruitless efforts can undermine the credibility of the organization. For example, Russia's unwillingness to involve the $\mathrm{CoE}$ in dealing with the issue of occupation of Crimea or parts of Georgian territory can be seen as one such failure. ${ }^{111}$

It might be argued that having some impact on recalcitrant States would be better than having no impact at all if these States are expelled. Having said that,

of Human Rights Turned a Blind Eye to Alleged Rights Abuses in Turkey?' (EJIL: Talk!, 28 December 2016) <https://www.ejiltalk.org/has-the-european-court-of-human-rights-turned-ablind-eye-to-alleged-rights-abuses-in-turkey/>.

106 'Reconsideration on Substantive Grounds of the Previously Ratified Credentials of the Russian Delegation' Res 1990 (2014), PACE, <http://website-pace.net/documents/10643/110596/ 20140410-Resolution1990-EN.pdf/57ba4bca-8f5f-4b0a-8258-66ca26f7117b $>2$.

107 L Mälksoo, 'The Paradox of a Human Rights Backlash' in L Mälksoo and W Benedek (eds), Russia and the European Court of Human Rights (Cambridge University Press 2018) 5.

108 'Report on Azerbaijan' (Human Rights Watch) < https://www.hrw.org/world-report/2017/ country-chapters/azerbaijan>; 'List of Political Prisoners' <https://humanrightsaz.wordpress.com/ list-of-political-prisoners/>; 'President Macron: Support Political Prisoners in Azerbaijan' (Freedom Now, 11 July 2017) <http://www.freedom-now.org/news/president-macron-supportpolitical-prisoners-in-azerbaijan/>.

109 Insanov v Azerbaijan, no 16133/08 (14 March 2013); Mahmudov and Agazade v Azerbaijan, no 35877/04 (18 December 2008).

110 We are aware of the fact that according to Art $1(\mathrm{~d})$ of the CoE Statute matters relating to national defence do not fall within the scope of the $\mathrm{CoE}$, however every conflict has a major human rights and rule of law aspect to it. The $\mathrm{CoE}$ could have potentially contributed there.

111 'Council of Europe's Rights Chief Decries Abuses, Says Russia "Only Country Not Cooperating", (Radio Free Europe, 27 September 2017) <https:/www.rferl.org/a/muizneksrussia-chechnya-azerbaijan-crimea-council-europe/28760684.html>. 
there is no guarantee that the Council would ever have any effect on the States that systematically undermine the purposes of the organization; if this effect was significant the questions about expulsion would not emerge at all. The argument in favour of admitting a State such as Russia in the first instance rested on the idea that it would lead to a modification of behaviour - if that has not happened to date then future predictions about an impending change need to be treated with a degree of scepticism. ${ }^{112}$ If the State concerned does not engage with the organization or merely imitates engagement then a possible future impact cannot be the crucial argument in order to preserve its membership. ${ }^{113}$

This discussion shows that in some circumstances the desire of an international organization to keep a State that clearly fails to comply with its statutory aims can undermine the importance of this organization. In such a case, an expulsion is a healthier option for the legitimacy and effectiveness of such organization.

\section{The domino effect}

The CoE should consider if expulsion would lead to other Member States leaving the organization. An organization that is concerned about its selfpreservation should take into account that if one Member State leaves or is expelled then this might create an incentive for other countries to do the same. Although, this is an intuitively appealing argument, the history of international organizations does not necessarily support it. The CoE did not fall when Greece left it in the 1960s. In America, Trinidad and Tobago and Venezuela - countries with significant problems in the area of human rights -have denounced the American Convention on Human Rights ${ }^{114}$ and the Inter-American Court of Human Rights continued its existence. A number of States withdrew from the United Nations Industrial Development Organization and it is still in full operation. ${ }^{115}$

Based on these historical examples there are three types of scenarios when expulsion can threaten the existence of an international organization. First, a domino effect is perhaps possible if there is a growing dissatisfaction with the organization among a large number of its Member States. For example, the failure of the League of Nations to prevent the outbreak of the Second World

112 See A Drzemczewski, 'Human Rights in Europe: an Insider's Views' (2017) EHRLR 134.

113 The States express a wide variety of reactions to the judgments of the ECtHR. See D Anagnostou, 'Untangling the Domestic Implementation of the European Court of Human Rights' Judgments' in D Anagnostou (ed), Implementing Strasbourg's Judgments on Domestic Policy (Edinburgh University Press 2013) 8. If the reaction is predominantly negative or formalistic, then the impact of the CoE is limited.

114 See 'Venezuela Denounces American Convention on Human Rights as IACHR Faces Reform' (International Justice Resource Center, 19 September 2012) <http://www.ijrcenter.org/ 2012/09/19/venezuela-denounces-american-convention-on-human-rights-as-iachr-faces-reform/ $>$.

115 'Former Member States, UN Industrial Development Organization'<https://www.unido.org/ who-we-are/structure/member-states/former-member-states $>$. 
War meant that it was replaced by the United Nations after the cessation of hostilities. The second scenario takes place when a Member State which is dominant in a particular organization withdraws. In this situation an international organization is likely to collapse as a result. For example, the withdrawal of the Soviet Union from the Warsaw Pact signified the effective end of this organization. ${ }^{116}$ Finally, a collapse of an organization would be imminent if it only consists of two States parties and one of them decides to withdraw. ${ }^{117}$ None of these scenarios is applicable to the CoE. There is no dominant member that can destroy the organization. It is made of $47 \mathrm{Member}$ States and the expulsion of one, or even all, of the States which we identify in this article would not signify its collapse. The most challenging pretext for a domino effect in the context of the CoE would be if the majority of the Member States are dissatisfied with it. This is a more subjective criterion but it is unlikely that withdrawal or expulsion of a State from the CoE would trigger the withdrawal of those States that express commitments to human rights, democracy and the rule of law even if they are also not fully satisfied with the activities of the Council. In other words, it is unlikely that Turkey's expulsion would trigger the withdrawal of, say, Germany or France.

Despite the fact that a mass exodus of the Member States is unlikely, the CoE statutory bodies should take into consideration how expulsion will influence its further relation with the remaining Member States, potential Members, States worldwide and other international organizations. The risk with expulsion of a member from an international organization is that it does not act as a lesson for other recalcitrant members; it changes the institutional dynamic within the international organization itself so that it becomes more averse to taking action in relation to other misbehaving members. When apartheid South Africa, under threat of ejection, ${ }^{118}$ withdrew from the International Labour Organisation, the behaviour of Portugal in relation to its African territory was largely ignored, despite consistent criticism of Lisbon's policies. ${ }^{119}$ In a circumstance where the $\mathrm{CoE}$ expelled States that undermine its statutory aims, one has to consider the effect that this would have in relation to other members-would it mean that the CoE organs would then be less interventionist in order to prevent further damage to the institutions? As an

\footnotetext{
116 C Bohlen, 'Warsaw Pact Agrees to Dissolve Its Military Alliance by March 31' (New York Times, 26 February 1991) <http:/www.nytimes.com/1991/02/26/world/warsaw-pact-agrees-todissolve-its-military-alliance-by-march-31.html>.

117 A Hughes 'The Collapse of the Senegambian Confederation' (1992) 30 Journal of Commonwealth \& Comparative Politics 200.

118 See "Declaration concerning the Policy of "Apartheid" of the Republic of South Africa' (1964) vol XLVII, no 3 International Labour Office Official Bulletin.

119 D Maul, Human Rights, Development and Decolonization: The International Labour Organization, 1940-70 (Palgrave Macmillan 2012) 244-5.
} 
example, how would it influence, if at all, the gradual integration of Belarus ${ }^{120}$ into the orbit of the Convention system?

\section{Financial stability}

An international organization cannot exist, let alone effectively fulfil its aims, without funding. Financial considerations are not ends themselves; they remain a means to an end, but they are nonetheless important. States such as Russia and Turkey pay a substantial contribution to the budget of the CoE. There are at least three factors that should be taken into account here. First, and most significant, is that the CoE is based on liberal values. If financial stability dominates the Council's approach to Article 7 then it can be accused of crude realism undermining its raison d'être. An approach according to which money can overshadow some lack of commitment might undermine all those useful and beneficial projects that the $\mathrm{CoE}$ can facilitate using these money. Second, States can stop paying their contributions without being expelled from the organization. This puts the $\mathrm{CoE}$ in a position of austerity as its activities are budgeted with the full contribution in mind. Therefore, some substantive cuts need to be made if a Member State fails to pay. This makes the normal operation of the $\mathrm{CoE}$ challenging. Finally, it is not clear that the withdrawal of funds might not be offset by the corresponding decrease in caseload to the institutions of the CoE.

Of course, it is not possible to provide an exact calculation of the contributions and expenditures of an organization like the CoE; it is often not possible to single out a particular country that benefits from the activities of the $\mathrm{CoE}$ and how this benefit is calculated. Having said this, we can use the caseload of the ECtHR as an indicator that demonstrates how burdensome some States might be. As was pointed out in Section V.B.2, the Russian Federation and Turkey alongside France, Italy, Germany and the UK were the major contributors to the ordinary budget of the $\mathrm{CoE}$ and collectively they were responsible for 65 per cent of this budget. It means that each of them covers around 11 per cent of the budget. In 2017, 12.2 per cent of pending cases of the European Court of Human Rights were submitted against Russia and 12.2 per cent against Turkey. ${ }^{121}$ This means that the share of Turkey and Russia in the case load of the ECtHR is bigger than their share in the budget of the ECtHR. While the correlation between the budget and the number of pending cases is not a direct one, this analysis can be used to illustrate that the CoE will not necessarily be worse off financially if it expels Member States who are human rights offenders.

\footnotetext{
120 Belarus is not a member of the Council of Europe.

121 'Pending Applications Allocated to a Judicial Formation, 30/11/2017'<http://www.echr.coe. int/Documents/Stats_pending_2017_BIL.pdf>.
} 


\section{B. Protection of Human Rights}

Protection of human rights, democracy and rule of law is the key objective of the CoE. The set of calculations considered here analyses whether a potential worsening of individual human rights protection in the expelled States can justify a less rigorous interpretation of Articles 7 and 8 of the Statute of the CoE. It is important to stress that this type of calculation is not arithmetic; the decision-maker needs to accept a lot of approximations in concluding how effective the $\mathrm{CoE}$ is in securing human rights in the States which are unwilling to participate sincerely in its operation. Although undoubtedly rights of some individuals might be affected by the expulsion this section argues that it would not affect the expelled State on the strategic levelnamely, democratization and protection of human rights within the State. Here, we will examine the inability of victims of human rights violations to bring applications to the ECtHR against the expelled States. There are many more areas in which expulsion can potentially reduce human rights protection of individuals. For example, Protocols 6 and 13 to the Convention, which prohibit the reintroduction of the death penalty, would not be applicable in an expelled State as well as various conventions and activities of the CoE that are designed to improve human rights protection in its Member State. ${ }^{122}$ Beyond the ECtHR, there are many more CoE human rights bodies that monitor human rights commitments of the Member States. ${ }^{123}$ It seems, however, that the ECtHR is the most significant part of the Strasbourg machinery of human rights protection and therefore we will mainly consider it.

Expulsion from the CoE will signify that any person under the jurisdiction of the former Member State whose rights are allegedly violated will lose an opportunity to apply to the ECtHR. The Secretary General of the CoE has identified this as one of the key challenges of expulsions or withdrawals. On the example of Russia he pointed out that: '[i]t would really be very, very bad if Russia was to leave . . because the convention and court has been so important for Russian citizens'. ${ }^{124}$ Indeed, millions of people might lose the right to apply to the ECtHR. ${ }^{125}$ This will likely reduce the level of international supervision on the compliance with human rights standards in these States.

At this stage, one, however, needs to consider whether the ECtHR has been indeed 'so important for [the] citizens' of the States with a questionable human

\footnotetext{
122 This may be protected under other international human rights instruments, eg Turkey ratified the Second Optional Protocol to the International Covenant on Civil and Political Rights in 2006, although this varies by country and treaty.

${ }^{123}$ For example, the Committee for the Prevention of Tortures, the European Committee of Social Rights just to name a few.

124 N Buckley, 'Russia Tests CoE in Push to Regain Vote' (Financial Times, 26 November 2017) $<$ https://www.ft.com/content/3cccaf92-d12c-11e7-b781-794ce08b24dc>.

125 Pursuant to art 1 the ECHR is only applicable to everyone who appears to be within the jurisdiction of the Contracting Parties to the Convention.
} 
rights record. Of course, the Court is influential in cases which are not politically sensitive and are not considered threatening or important by the authorities. ${ }^{126}$ Often it is difficult to trace various changes in national law back to the ECtHR but these changes were clearly happening while Russia or other possible candidates for expulsion were members of the Council. ${ }^{127}$ Having said that, all these changes were not enough to firmly fix their political and legal system in the principles of human rights, democracy and rule of law. Roter argues that Russia, for example, is using an à la carte approach to the standards of the CoE. ${ }^{128}$ This means that the rights of some people in politically non-sensitive cases will lose an extra level of protection in the event of expulsion. This argument might be mitigated by the fact that the expelled States might be signatories to other international human rights regimes such as the UN Human Rights Committee. Moreover, the existence of Member States within the Strasbourg system is predicated on the basis that the States concerned were supposed to create a domestic system of human rights protection. If that did not happen it leads us to our core argument in this section, namely, that solution of individual cases cannot justify membership of such States in the CoE.

The drafters of the Convention considered that its key purpose is preventing the systemic reduction in protection of rights and freedoms and establishment of a non-democratic government. ${ }^{129}$ This function of the Court is commonly referred to as constitutional. ${ }^{130}$ The Court is less effective in fulfilling this

\footnotetext{
126 de Londras and Dzehtsiarou (n 36).

127 See A Kovler, 'Russia: European Convention on Human Rights: Fifteen Years After' in I Motoc and I Ziemele (eds), The Impact of the ECHR on Democratic Change in Central and Eastern Europe (Cambridge University Press 2016); A Burkov 'The Use of European Human Rights Law in Russian Courts' in L Mälksoo and W Benedek (eds), Russia and the European Court of Human Rights (Cambridge University Press 2018); L Mälksoo, 'Introduction: Russia, Strasbourg, and the Paradox of a Human Rights Backlash' in L Mälksoo and W Benedek (eds), Russia and the European Court of Human Rights (Cambridge University Press 2018); F van der Vet, 'Holding on to Legalism: The Politics of Russian Litigation on Torture and Discrimination Before the European Court of Human Rights' (2014) 23 Social and Legal Studies 361; Anagnostou (n 113); 'Impact of the European Convention on Human Rights in States Parties: Selected Examples' (Council of Europe, 8 January 2016) <http://website-pace.net/documents/ 19838/2008330/AS-JUR-INF-2016-04-EN.pdf/12d802b0-5f09-463f-8145-b084a095e895>.

${ }^{128}$ P Roter, 'Russia in the Council of Europe: Participation à la carte' in L Mälksoo and W Benedek (eds), Russia and the European Court of Human Rights (Cambridge University Press 2018).

129 E Bates, The Evolution of the European Convention on Human Rights (Oxford University Press 2010) 44-76.

${ }^{130}$ One of the drafters of the Convention Tietgen pointed out 'Democracies do not become Nazi countries in one day. Evil progresses cunningly, with a minority operating, as it were, to remove the levels of control. One by one freedoms are suppressed, in one sphere after another. Public opinion and the entire national conscience are asphyxiated. And then, when everything is in order, the "Fuhrer" is installed and the evolution continues even to the oven of the crematorium.' Quoted in MW Janis and RS Kay, European Human Rights Law (Oxford University Press 1990) 28. This was said to support the initiative to establish the ECtHR.
} 
function than it is in its adjudicatory capacity. ${ }^{131}$ What the Court can do well is find violations in individual cases ${ }^{132}$ and perhaps identify structural problems in a particular area of the legal system. ${ }^{133}$ The adjudicatory function is very important and it can have an impact on the legal order. However, it is unlikely to have a crucial influence on a macro level. In other words, a judgment of the ECtHR or indeed any court is unlikely to be enough to protect democracy in a given country. Moreover, a State can damage the reputation of the ECtHR by ignoring its judgments. Azerbaijan has demonstrated a continuing inability to comply with the judgments of the ECtHR. ${ }^{134}$ Members of the Russian Government have threatened that Russia will start ignoring the judgments of the ECtHR. ${ }^{135}$ The most sensitive cases are not executed and political reforms that would prevent such sensitive cases from happening are not undertaken.

This situation indicates that the ECtHR is not likely to trigger a structural change in the Member State especially if the Member State in question is resistant to such changes. What is important here is not only the sheer scale of unexecuted judgments but the lack of the authorities' genuine willingness to at least try to implement these judgments. This distinguishes the situation in Russia or Azerbaijan from the situation in Ukraine which also has a large number of cases pending before the Committee of Ministers. ${ }^{136}$ The Ukrainian authorities consistently confirm their commitment to the values of human rights, democracy and the rule of law. At least to a certain degree, a difficult economic and political situation in Ukraine is to be blamed for failures to implement certain judgments.

The judgments of the ECtHR cannot effectively socialize States which are not interested in protection of human rights and furthering democracy. Moreover, keeping them within the system hoping that they will begin to socialize seems counterproductive. Roter rightly points out that '[i]nternational governmental organizations, as institutions with Member States that adhere to the principle of sovereign equality of States, have hardly any suitable means to induce, if not force, socialization in their Member States'. ${ }^{137}$ In the absence of voluntary socialization, which appears not to have occurred in the cases outlined above, there is a clear disjunction between the actions of such Member States and the values of the CoE. Therefore, continued membership

131 Bates (n 129) 171-264; and K Dzehtsiarou and A Greene, 'Restructuring the European Court of Human Rights: Preserving the Right of Individual Petition and Promoting Constitutionalism' (2013) PL 710.

${ }_{132}$ See eg Marckx v Belgium (13 June 1979) Series A no 31.

133 See eg Burdov v Russia (no 2), no 33509/04 (15 January 2009).

134 Ilgar Mammadov v Azerbaijan (n 91); Sargsyan v Azerbaijan, no 40167/06, ECHR 2015; Gafgaz Mammadov v Azerbaijan no 60259/11 (15 October 2015).

135 Speaker of the Russian Senate claimed that Russia will not recognize the judgments of the ECtHR. Матвиенко заявила об отказе России признавать решения ЕСПЧ из-за ПАСЕ, РБК, $<$ https://www.rbc.ru/politics/09/10/2017/59db7cdc9a79470249c79eba>.

136 'Country Factsheet. Ukraine' <https://rm.coe.int/1680709769>.

137 Roter (n 128) 51-2. 
of a State merely to plug some holes in the legal system which are not considered serious or threatening to the distribution of power in the countries might be counterproductive.

\section{CONCLUSION}

There is no consensus among commentators as to whether the sanctions of last resort, namely suspension and expulsion, should be ever used by international organizations. We argued that a regional organization like the CoE that is designed to protect human rights, democracy and the rule of law should apply such sanctions if there is a legal right to do so, if there are clear signs of crisis and it is more beneficial for the legitimacy, effectiveness and reputation of the international organization to expel recalcitrant members. We must acknowledge here that the key decision-maker, the Committee of Ministers of the CoE, is a political body, which might indicate an unwillingness to suspend or expel Member States. This should not, however, be taken to mean that they would not exercise such powers, perhaps reluctantly, if the circumstances dictate that this is necessary. In this case the State in question might pull out of the $\mathrm{CoE}$ before the formal procedure is over.

In this article we have adumbrated various considerations which might influence the decision about deployment of suspension or expulsion. If a particular State undermines the founding principles of the organization it needs to be decided if expulsion of this member is more or less detrimental to the organization than its continuing membership. When expulsion becomes less detrimental the CoE has to apply Articles 7 and 8 of the Statute. It is also crucially important that the Strasbourg system is capable of changing human rights protection on a macro level. If this is not possible in the State at hand, some worsening of human rights protection in individual cases cannot justify continuation of membership.

These factors create a framework for assessment of the situation in relation to particular Member States. It cannot offer definite answers in difficult situations and a lot will depend on how this framework is approached. That said, it provides the decision-makers in Strasbourg and in the Member States with a test that can be applied to the States that fail to cooperate with the CoE. 